\title{
WEB
}

WISSENSCHAFTSZENTRUM BERLIN FÜR SOZIALFORSCHUNG

SOCIAL SCIENCE RESEARCH CENTER BERLIN

\author{
Kjell Erik Lommerud * \\ Frode Meland ** \\ Odd Rune Straume ***
}

\section{Can Deunionization Lead to International Outsourcing?}

* University of Bergen

** University of Bergen

*** University of Minho

SP || $2006-23$

December 2006

ISSN Nr. $0722-6748$

Research Area

Markets and Politics

Research Unit

Market Processes and Governance
Schwerpunkt

Märkte und Politik

Abteilung

Marktprozesse und Steuerung 
Zitierweise/Citation:

Kjell Erik Lommerud, Frode Meland, Odd Rune Straume, Can Deunionization Lead to International Outsourcing?, Discussion Paper SP || 2006 - 23, Wissenschaftszentrum Berlin, 2006.

Wissenschaftszentrum Berlin für Sozialforschung $\mathrm{gGmbH}$, Reichpietschufer 50, 10785 Berlin, Germany, Tel. (030) 25491 - 0 Internet: www.wz-berlin.de 


\section{ABSTRACT}

\section{Can Deunionization Lead to International Outsourcing?}

by Kjell Erik Lommerud, Frode Meland and Odd Rune Straume *

We analyze unionized firms' incentives to outsource intermediate goods production to foreign (low-cost) subcontractors. Such outsourcing leads to increased wages for the remaining in-house production. We find that stronger unions, which imply higher domestic wages, reduce incentives for international outsourcing. Though somewhat surprising, this result provides a theoretical reconciliation of the empirically observed trends of deunionization and increased international outsourcing in many countries. We further show that globalization - interpreted as either market integration or increased product market competition - will increase incentives for international outsourcing.

Keywords: International outsourcing, deunionization, globalization

JEL Classification: F16, J51, L24

\section{ZUSAMMENFASSUNG}

\section{Führt der Rückzug der Gewerkschaften zur internationalen Auslagerung von Arbeitsplätzen?}

Im Papier werden die Anreize untersucht, aufgrund derer Unternehmen mit gewerkschaftlich organisierten Beschäftigten die Produktion von Zwischengütern in Niedriglohnländer auslagern. Dieses Outsourcing führt zu höheren Löhnen für die im Inland verbleibende Produktion. Es wird gezeigt, dass starke Gewerkschaften, die für höhere Löhne am inländischen Standort sorgen, die Anreize für die Auslagerung verringern. Dieses theoretische Ergebnis bringt überraschenderweise - die empirischen Beobachtungen in Übereinstimmung, dass einerseits im Trend die gewerkschaftliche Organisation schwächer wird und andererseits gleichzeitig internationales Outsourcing in vielen Ländern zunimmt. Globalisierung - definiert als Integration von Märkten oder verstärkter Wettbewerb im Produktmarkt - wird die Anreize für internationales Outsourcing weiter verstärken, wie hier gezeigt werden kann.

\footnotetext{
* We would like to thank Michel Dumont and participants at a 2005 CESifo conference on Employment and Social Protection for useful discussions.
} 


\section{Introduction}

Many fear the consequences of globalization for 'ordinary workers' in the developed world. Will their jobs disappear to countries where labour costs are only a fraction of what they are in Western Europe and the US? Perhaps the rich world is left with 'the new enterprise' where highly skilled workers perform a firm's core activities - and where everything that can be outsourced to low-income countries, is in fact outsourced. What will then happen to the lesser skilled?

An interesting question concerns the role of trade unions in such a situation. Are they the cause behind job losses in rich countries? Could it be that weaker unions would lead to more flexible wage setting, so that job losses could have been prevented - albeit at the price of higher wage dispersion among skilled and unskilled workers?

The role of trade unionism has evolved dramatically differently in different countries over the recent years. ${ }^{1}$ The perhaps most drastic example of deunionization is the UK, where the percentage of workers covered by collective bargaining has fallen sharply over the last 15 years. The US always had weaker unions than Europe, but also there union coverage has been falling, albeit from a level that was low to begin with. In Continental Europe and Scandinavia union coverage is almost unchanged. Many of these countries are characterized by more centralized bargaining systems than in the UK and the US, and union membership rates remain at a high level. There are also a couple of countries, notably France and Portugal, where membership rates have fallen to quite low levels, but where union coverage - the percentage of the workforce that is covered by collective agreements - is still very high.

If trade unions and a lack of downwards wage-flexibility were important factors behind firms' rush to outsource tasks to low-income countries, one would expect that outsourcing was more prevalent in countries with strong unions than in countries with weak unions. The facts do not seem to support this notion. Although it is not easy to find good data on country-wide outsourcing, one possible measure that may capture in-

\footnotetext{
${ }^{1}$ Some core facts are documented in OECD (1997) and EEAG (2004).
} 
ternational outsourcing activities is the share of parts and components (input factors) in total imports. In Figure 1, we use data on this share found in Yeats (2001), and plot them against bargaining coverage levels - which is arguably the most relevant measure of the degree of unionization in a country - from OECD (1997), augmented by data from Dell'Aringa et al. (2004) for the case of Ireland.

Share of parts and components in total imports (SpcI) vs. bargaining coverage (BC) (both in \%).

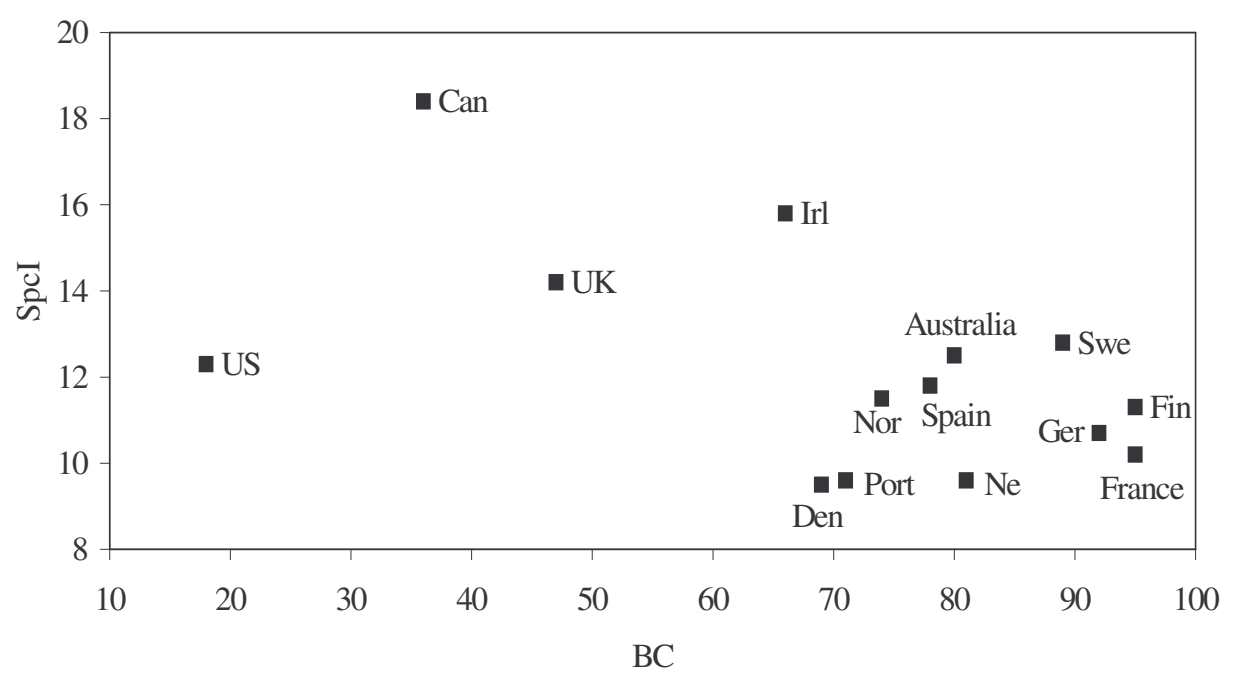

Figure 1

It is not advisable to draw any strong conclusions from such a picture, although it suggests that parts and components constitute a relatively low share of total imports for countries with high bargaining coverage rates. This is the opposite of what one would expect if trade unionism drove outsourcing. The US is an outlier in this figure, maybe because of the much larger possibility of US firms to outsource domestically due to the presence of many potential domestic subcontractors. ${ }^{2}$ One could alternatively see Canada as the outlier (perhaps because Canadian production is so interrelated with what goes on in the US); then the impression becomes that outsourcing is rather independent of the strength

\footnotetext{
${ }^{2}$ Of course, this effect must also dominate the similar effect that makes final good imports low, due to the presence of many final goods manufacturers in a large country.
} 
of unions. ${ }^{3}$

This paper presents a theoretical model of deunionization and outsourcing decisions. The main result of the analysis is that deunionization can in fact trigger outsourcing. The main building block behind this argument is that as more and more tasks are outsourced, the incentives for the remaining workforce to show wage restraint are weakened. Deunionization reduces the wage hike following outsourcing - and makes outsourcing more attractive. This suggests that union bashing is not an effective way to preserve jobs and income opportunities for lesser skilled workers in rich countries.

There is a quite substantial existing literature that studies theoretically the effect of globalization (most often taken to mean trade liberalization) on outcomes for unionized workers. Both Staiger (1988) and Naylor $(1998,1999)$ present models where unionized labor in fact might benefit from globalization. For example, Naylor presents a rather rosy picture: Unionized workers gain both in terms of higher wages and in terms of more jobs. He works within a model where firms have oligopoly power and where there is monopoly trade union wage setting. Trade liberalization means more competition in the market: This lowers firms' profits, but also expands total production in the market. Firms lose market shares at home, but they gain shares abroad, and total production goes up. This leads to higher labor demand - which the union manages to translate both to higher wages and more jobs. Lommerud, Meland and Sørgard (2003) present a model where the foreign country is a nonunionized low-cost producer and where the firm can move production out of the country, partly or fully. They warn that the picture then becomes more complex, but there is a tendency that unionized workers can suffer from globalization. In fact, it is exactly the possibility that unionized wages go up following trade liberalization that makes 'offshoring' of final goods production more attractive. ${ }^{4}$

\footnotetext{
${ }^{3}$ It has been suggested to us that since, following Machin (2000), deunionization could be a result of increased importance of new industries, we could circumvent this potential problem by using coverage and imports related to manufactures only. The limited data we found (not reported) does still not seem to run contrary to our main result.

${ }^{4}$ In a related setting of unionized international oligopoly, Lommerud, Straume
} 
International outsourcing of intermediate input production is barely mentioned in the literature on trade unions and globalization. One exception is Skaksen and Sørensen (2001). ${ }^{5}$ They find that outward FDI (which is conceptually equivalent to international outsourcing) can lead the bargained wage to go up, provided that there is a sufficient degree of complementarity between the activities in the home country and the activities in the host country. This superficially resembles results as those of Staiger and Naylor, that unions can benefit from harder international competition. However, the basis for the Skaksen-Sørensen outsourcing result is quite different. They take as their starting point the well-known article by Horn and Wolinsky (1988). Horn and Wolinsky pointed out that unions could benefit (lose) from more fragmented ${ }^{6}$ (integrated) production if tasks where compliments (substitutes). Outsourcing typically means to move out some tasks that are complimentary to tasks that will stay in the firm, and the Skaksen-Sørensen result then follows as a variant of the Horn-Wolinsky finding.

In the present paper, we take the analysis a step further by developing a theoretical model equipped to answer how deunionization will affect outsourcing decisions. We find, perhaps surprisingly, that outsourcing incentives are inversely correlated with trade union strength, implying that strong unions can in effect deter outsourcing. Although consistent with the stylized facts, this result - which will be explained in detailed later - may appear quite counterintuitive, since another implication of stronger unions is higher in-house production costs. Establishing a theoretical relationship between deunionization and international outsourcing is the main contribution of the paper; however, we also use the model to study the interrelation of deunionization and outsourcing with technology level and globalization - in several different interpretations of the term.

Outsourcing, internationally and domestically, is a topical issue in

and Sørgard (2006) show that cross-border merger is another channel through which globalization might hurt unionized workers.

${ }^{5}$ See also Zhao (2001).

${ }^{6}$ 'Fragmented' here means that goods are produced by different firms that each has its own union. 
the recent economics literature. In the theory of the multinational firm there is a tradition where the international firm is assumed to be organized as it is because it has carefully considered the costs and benefits of the various alternatives (see, e.g., Markusen, 1995). Grossman and Helpman have recently written a much noted string of papers $(2002,2003$ and 2005) that can be seen as studying outsourcing in such a perspective: These models open up for many complications as search processes and contract incompleteness, but in the end the organizational structure of a firm is determined by the relevant costs and benefits of the various alternatives. ${ }^{7}$ There also exists a vein of literature that consider outsourcing decisions as strategic: ${ }^{8}$ The outsourcing decision itself influences the price structure that a firm faces. The theory of outsourcing with trade unions can be seen as an example of a strategic outsourcing theory: Outsourcing influences the wage rate the firm has to pay, and this in turn influences the outsourcing decision.

The present model sees production as a series of interrelated tasks, which in principle all can be outsourced to a foreign economy. In line with the tradition in international economics ${ }^{9}$, we choose to work with a model of monopolistic competition. Although we perform our analysis in a partial equilibrium setting, we think it is an advantage to work within the same framework as most recent studies of outsourcing - for example Grossman and Helpman's mentioned series of papers. This should make it easier at one point in time to integrate the insights from the standard theory on outsourcing on the one side and the theory on trade unions and outsourcing and other forms of competitive pressures from abroad on the other. ${ }^{10}$ We underline that our central results can be reproduced in a model of international Cournot oligopoly with linear

\footnotetext{
${ }^{7}$ From the vast recent literature on outsourcing, we mention Feenstra and Hanson (1999), Glass and Saggi (2001), Kohler (2004), Antràs and Helpman (2004), Görg, Hijzen and Hine (2005), and Thesmar and Thoenig (2002).

${ }^{8}$ See, for example, Lyons and Sekkat (1991), Chen, Ishikawa and Yu (2004), Shy and Stenbacka (2003) and Choi and Davidson (2004).

${ }^{9} \mathrm{See}$, for example, the well-known textbook by Dixit and Norman (1980).

${ }^{10}$ Blanchard and Giavazzi (2003) develop a model that combines monopolistic competition in the product market and bargaining in the labor market, and our model shares many traits with that work, but their focus is neither on firm structure nor on open economy issues.
} 
demand - a framework often favored by the literature on trade unions and globalization.

The remainder of this paper is organized as follows: Section 2 presents the model framework, while Section 3 studies wage bargaining and employment decisions within this format. Second 4 studies a firm's outsourcing decision, and the impact of deunionization on this decision. Section 5 analyzes how globalization will affect outsourcing, Section 6 considers two important extensions to the model, and Section 7 offers some concluding remarks.

\section{Model}

We consider an industry consisting of a large (and fixed) number of monopolistically competitive firms, indexed by $i$, each producing their own variety of a differentiated final good. Each firm produces the final good by using a continuum of inputs indexed by $j \in[0, \phi]$, where $\phi>0$. We allow the firms to differ with respect to productive efficiency by introducing a technology parameter $\gamma_{i}$ and assuming that one unit of the final good requires $\gamma_{i}^{-1}$ units of each input for firm $i$. Each input can either be produced domestically at the firm's plant or outsourced to a foreign supplier. ${ }^{11}$ In the case of in-house production, firm $i$ can produce one unit of any input $j$ by using one unit of labour at a wage rate $w_{i}$. Alternatively, the input can be acquired from a foreign supplier at an exogenous per-unit price $c$, which - for simplicity - is assumed to be equal for all inputs (and all firms). ${ }^{12}$

There are fixed costs associated with the outsourcing of each link in the production chain. These costs will typically include costly search for (and evaluation of) potential sub-contractors, costs of managing and supervising the contract, and coordination costs of linking different production processes. The firms may also have to pay severance packages for

\footnotetext{
${ }^{11}$ At this point it seems arbitrary to assume that outsourcing is by assumption international, but we will argue below that this is the natural way to proceed given how the model is constructed.

${ }^{12}$ Introducing cost heterogeneity by letting $c_{j}$ denote the per-unit price of input $j$ would not affect the qualitative nature of any of our results. However, the clarity of presentation is greatly enhanced by assuming that $c_{j}=c$ for all $j \in[0, \phi]$.
} 
laid-off workers. We assume that these costs vary with different inputs, where $g(j)$ is the cost of outsourcing input $j$. If we order the inputs on $[0, \phi]$ according to $g(j)<g(l)$ for $j<l$, the cost of outsourcing $k$ inputs is given by

$$
G(k)=\int_{0}^{k} g(j) d j .
$$

We assume that $G$ is twice differentiable with $G^{\prime}(k)>0, G^{\prime \prime}(k)>0$, $G^{\prime}(0)=0$ and $G^{\prime}(\phi) \rightarrow \infty$. The last assumption essentially means that it is not economical to outsource all production, even though it would be technically possible. ${ }^{13}$

The going wage rate for in-house production is determined in bargaining between each firm and its corresponding trade union, representing all workers in the firm. ${ }^{14}$ The trade unions are assumed to maximize total union rents, implying that the objective function of the trade union belonging to firm $i$ is given by

$$
U_{i}=\left(w_{i}-\bar{w}\right) n_{i}
$$

where $\bar{w}$ is an exogenous reservation wage (assumed to be equal for all workers in the industry), ${ }^{15}$ and $n_{i}$ is total employment (for in-house production) by firm $i$.

We assume that the producer of variety $i$ faces the following demand for the final good:

$$
y_{i}=\Gamma p_{i}^{-\sigma}, \quad \Gamma>0, \sigma>1
$$

where $p_{i}$ is the price of variety $i$. As is well known, a demand function of this type can be derived from individual utility maximization with CES utility functions, where $\sigma$ is the elasticity of substitution between

\footnotetext{
${ }^{13}$ This assumption is further discussed in the concluding section.

${ }^{14}$ The implicit assumption is that workers are homogeneous: they are all 'ordinary', unionized workers. The empirical paper by Geishecker and Görg (2004) warns us that this is not necessarily the case, so that international outsourcing can have winners and losers. In the concluding section we discuss the implications of enriching the model on this count.

${ }^{15}$ The reservation wage has several possible interpretations. For example, it can be thought of as the wage level in a perfectly competitive 'buffer' sector of the economy.
} 
the different varieties.

If firm $i$ has already outsourced the production of $k_{i}$ inputs, its operating profits are given by ${ }^{16}$

$$
\pi_{i}=\left[p_{i}-\gamma_{i}^{-1}\left(k_{i} c+\left(\phi-k_{i}\right) w_{i}\right)\right] y_{i}
$$

In line with the assumption of monopolistic competition, prices set by the other firms do not have a direct impact on the price-setting of an individual firm. In this respect, the actions of other firms are ignored. Each firm does, however, consider how its outsourcing decision affects the outcome of wage bargaining with its trade union. We propose the following sequence of events:

Stage 1: Each firm decides on the organization of production by choosing the number of inputs to be outsourced.

Stage 2: Each firm and its corresponding trade union bargain over the wage level that applies for in-house production.

Stage 3: Employment and prices for the final good varieties are set by each firm.

This particular sequence of events implies that firms have the 'right to manage', i.e., each firm unilaterally determines the level of employment after the wage has been negotiated with the trade union.

In a sense, the model is 'long-term': Workers, if equipped with sufficient bargaining power, can rationally set their wage level as they want it to be. It can seem that some globalization sceptics focus on the very short-term where nominal wage rigidities block workers from changing their wage given that international competition has become harsher, but here there are no such nominal rigidities. On the other hand, the model does not allow a trade union to promise moderate wages for a very long time to deter outsourcing. We think it is natural to view organizational structure as a long-term commitment that precedes wage bargaining. This assumption is commonplace but not ubiquitous in the literature on trade unionism under globalization.

\footnotetext{
${ }^{16}$ Here we treat the outsourcing $\operatorname{cost} G\left(k_{i}\right)$ as sunk.
} 


\section{Wage bargaining and employment}

Consider firm $i$. For given levels of outsourcing $\left(k_{i}\right)$ and wages $\left(w_{i}\right)$, profit maximizing price setting can be derived from (3) and (4), yielding the optimal price

$$
p_{i}\left(w_{i}, k_{i}\right)=(1+\mu) \omega \gamma^{-1}
$$

where

$$
\omega_{i}:=k_{i} c+\left(\phi-k_{i}\right) w_{i}
$$

Marginal production costs are $\omega \gamma^{-1}$, and

$$
\mu:=\frac{1}{\sigma-1}
$$

is the mark-up of the price over marginal production costs. Since this mark-up (and thus the firms' market power) is decreasing in $\sigma$, we can think of $\sigma$ as a measure of the degree of product market competition.

From (5) and (3) we can derive firm $i$ 's labor demand:

$$
n_{i}\left(w_{i}, k_{i}\right)=(\phi-k) \gamma_{i}^{-1} y_{i}\left(w_{i}, k_{i}\right)=(\phi-k) \gamma_{i}^{\sigma-1} \Gamma(1+\mu)^{-\sigma} \omega_{i}^{-\sigma}
$$

Note that better technology (higher $\gamma$ ) increases the demand for labor. There are two opposing forces at work. On the one hand, better technology reduces the marginal cost of production, $\omega \gamma^{-1}$, which - all else equal - increases labor demand. On the other hand, superior technology also implies that a given quantity of the final good can be produced using fewer workers, which has the opposite effect on labor demand. The first effect dominates when demand is elastic, i.e., $\sigma>1 .^{17}$

It is also instructive to derive the wage elasticity of labor demand, which is found to be

$$
\varepsilon_{i}:=-\frac{\partial n_{i}\left(w_{i}, k_{i}\right)}{\partial w_{i}} \frac{w_{i}}{n_{i}\left(w_{i}, k_{i}\right)}=\lambda_{i} \sigma,
$$

\footnotetext{
${ }^{17}$ See Dowrick and Spencer (1994) and Lommerud, Meland and Straume (2006) for more detailed analyses of the labour demand effect of introducing labour-saving technologies.
} 
where

$$
\lambda_{i}:=\frac{\left(\phi-k_{i}\right) w_{i}}{\omega_{i}} \in[0,1]
$$

is unionized (domestic) labor's share of total production costs in firm $i$. Note that increased international outsourcing reduces domestic labor's cost share, i.e., $\partial \lambda_{i} / \partial k_{i}<0$, which leads to a corresponding reduction in labor demand elasticity.

We apply the Nash bargaining solution to determine the outcome of the wage bargaining between the firms and their corresponding trade unions. Assuming zero disagreement payoffs, the Nash maximand for wage bargaining in firm $i$ is given by

$$
\Omega_{i}=\alpha \ln U_{i}+(1-\alpha) \ln \pi_{i},
$$

where $\alpha \in(0,1)$ denotes the relative bargaining strength of the union. We assume that the relative bargaining strength is equal for all firmunion pairs. From the first-order condition of the Nash bargaining problem, $\partial \Omega / \partial w_{i}=0$, we can derive the equilibrium wage for any given level of outsourcing $k_{i} \in(0, \phi)$. This wage is given by

$$
w_{i}\left(k_{i}\right)=\bar{w}+\alpha \mu\left[\bar{w}+\frac{k_{i}}{\phi-k_{i}} c\right] .
$$

The wage is the fall-back wage plus a share in rents, and rents are a mark-up on the real resource cost of production.

The corresponding employment level is given by

$$
n_{i}\left(k_{i}\right)=\left(\phi-k_{i}\right) y_{i}\left(k_{i}\right)=\left(\phi-k_{i}\right) \gamma_{i}^{\sigma-1} \Gamma(1+\mu)^{-\sigma}(1+\alpha \mu)^{-\sigma} \bar{\omega}_{i}^{-\sigma},
$$

where

$$
\bar{\omega}_{i}:=k_{i} c+\left(\phi-k_{i}\right) \bar{w} .
$$

Finally, inserting (8) into (5), we can derive the optimal price level

$$
p_{i}\left(k_{i}\right)=\gamma_{i}^{-1}(1+\mu)(1+\alpha \mu) \bar{\omega}_{i},
$$

which reflects the 'double marginalization' feature of the model. 
Considering the effect of outsourcing on wages, our first important result - which provides a building block for the subsequent results of the paper - follows directly from (8):

\section{Proposition 1 Outsourcing increases the bargained wage}

This result illustrates a main mechanism of the model. If a firm outsources more production, the domestic trade union will respond by enforcing higher wages for the remaining in-house production. The intuition follows from the aforementioned effect of outsourcing on the wage elasticity of labor demand. Increased outsourcing has the effect of 'exogenizing' a larger share of marginal production costs. This means that a wage increase has a smaller effect on marginal production costs and thus causes a smaller decrease in labor demand. Consequently, increased outsourcing makes labor demand less elastic. When labor demand gets less elastic, the wage/employment trade-off becomes more favorable for the trade union, with a higher bargained wage as the result. It also follows directly from (8) that the size of the wage response to increased outsourcing is an increasing function of the market power of firms $(\mu)$ and the relative bargaining power of unions $(\alpha)$.

The effect of outsourcing on employment in firm $i$ is the sum of a direct and an indirect effect:

$$
\frac{\partial n_{i}\left(k_{i}\right)}{\partial k_{i}}=\frac{\partial n_{i}\left(w_{i}, k_{i}\right)}{\partial k_{i}}+\frac{\partial n_{i}\left(w_{i}, k_{i}\right)}{\partial w_{i}} \frac{\partial w_{i}\left(k_{i}\right)}{\partial k_{i}} .
$$

For a given wage level, outsourcing has an ambiguous effect on employment. From (6) we find that

$$
\frac{\partial n_{i}\left(w_{i}, k_{i}\right)}{\partial k_{i}}=y_{i}\left(w_{i}, k_{i}\right) \gamma_{i}^{-1}\left[\frac{\sigma\left(\phi-k_{i}\right)\left(w_{i}-c\right)}{\omega_{i}}-1\right]
$$

If $w_{i}>c$, outsourcing will reduce marginal production costs, which, in turn, will induce the firms to increase output. Thus, despite the direct job losses, increased outsourcing may increase labor demand if the remaining in-house production is sufficiently expanded. This will be the case if labor demand is sufficiently elastic. 
We already know from Proposition 1 that the second term in (11) is negative. Using (6) and (8), the total effect of international outsourcing on domestic employment is given by

$$
\frac{\partial n_{i}\left(k_{i}\right)}{\partial k_{i}}=y_{i}\left(k_{i}\right) \gamma_{i}^{-1}\left[\frac{\sigma\left(\phi-k_{i}\right)\left(\bar{w}_{i}-c\right)}{\bar{\omega}_{i}}-1\right],
$$

which closely parallels (12). Provided that $\bar{w}_{i}>c$, a higher degree of product market competition $(\sigma)$ will increase labor demand elasticity and enhance the probability of a positive relationship between international outsourcing and domestic employment. When seen in conjunction with Proposition 1, it follows that the possibility of direct exports of jobs (in the form of international outsourcing) being unambiguously positive for the trade union - due to higher wages and increased domestic employment - cannot be ruled out. We return to this issue in Section 6 .

\section{Outsourcing}

In this Section, we turn to the optimal outsourcing decisions of firms. The first-period problem facing firm $i$ is to choose the degree of outsourcing that maximizes present-value profits, $\Pi_{i}$. Abstracting from discounting, the optimal degree of outsourcing is given by

$$
k_{i}^{*}=\arg \max \left\{\Pi_{i}\left(k_{i}\right)=\pi_{i}\left(k_{i}\right)-G\left(k_{i}\right)\right\} .
$$

Inserting (8) and (10) into (3)-(4), we have that

$$
\pi_{i}\left(k_{i}\right)=\Gamma \gamma_{i}^{\sigma-1} \mu(1+\mu)^{-\sigma}(1+\alpha \mu)^{1-\sigma} \bar{\omega}_{i}^{1-\sigma},
$$

from which we can derive the first-order condition for (14), given by ${ }^{18}$

$$
\frac{\partial \prod_{i}}{\partial k_{i}}=(1+\alpha \mu) \gamma_{i}^{-1}(\bar{w}-c) y_{i}\left(k_{i}^{*}\right)-G^{\prime}\left(k_{i}^{*}\right)=0 .
$$

An interior solution, i.e., $k_{i}^{*}>0$, requires that the first term in (16) is positive. We see that this is only the case if $\bar{w}>c$. This establishes the following result:

\footnotetext{
${ }^{18}$ Our assumptions on $G(\cdot)$ ensure that the second-order condition is satisfied.
} 
Proposition 2 A firm will not outsource the production of any input unless it can be obtained at a price lower than the domestic reservation wage.

Whether or not a firm finds it profitable to outsource any parts of production is, perhaps surprisingly, not determined by the actual in-house production costs but rather by the reservation wage of domestic workers. This result is a consequence of the union response to outsourcing (Proposition 1). As long as some part of production remains in-house, outsourcing does not impede the union's ability to extract rents. The union will simply respond by enforcing higher wages for the remaining domestic production. Consequently, the profitability of outsourcing depends on total available rents - not actual production costs - in the industry. If $\bar{w}<c$, outsourcing implies that total rents are reduced, which harms both the union and the firm.

In the following, we will assume that the condition $\bar{w}>c$ is satisfied, implying that firms will outsource parts of production to foreign sub-contractors in equilibrium. ${ }^{19}$ Note also from (13) that $\bar{w}>c$ is a necessary (but not sufficient) condition for outsourcing to increase in-house employment. However, although international outsourcing may not always increase employment, the intuition behind Proposition 2 suggests that unionized workers nevertheless benefit in terms of total union rents. From (8) and (9) we can derive the expression for union utility:

$$
U_{i}\left(k_{i}\right)=\left[w_{i}\left(k_{i}\right)-\bar{w}\right] n_{i}\left(k_{i}\right)=\alpha \mu \bar{\omega}_{i}^{1-\sigma} \Gamma \gamma_{i}^{-1}(1+\mu)^{-\sigma}(1+\mu \alpha)^{-\sigma} .
$$

It is easily confirmed that $\partial U_{i}\left(k_{i}\right) / \partial k_{i}>0$, implying that a higher degree of outsourcing always increases union rents.

\subsection{Deunionization}

How does union strength affect firms' incentives for international outsourcing? On a more general level, it is reasonable to assume that the

\footnotetext{
${ }^{19}$ Here we see that international outsourcing is the natural assumption. Since potential subcontractors must have production costs below domestic reservation wages for outsourcing to be an option for domestic firms, it is natural to interpret this as outsourcing from 'high-cost' to 'low-cost' countries.
} 
bargaining power of trade unions is related to a number of different features of the labor market, ranging from union membership and coverage of collective agreements to regulatory features such as legal rules on the right to strike. However, in addition to the considerable increase in the prevalence of international outsourcing, the last few decades have also witnessed a process of deunionization in several countries - particularly in the US and UK - where labor market deregulation has been accompanied by a decline in union membership. Can these two empirical trends be theoretically reconciled? In our model, interpreting the parameter $\alpha$ as an inverse measure of deunionization, we can establish the following causal relationship between deunionization and outsourcing:

Proposition 3 Deunionization leads to increased international outsourcing.

Proof. By total differentiation of (16) we obtain

$$
\frac{\partial k_{i}^{*}}{\partial \alpha}=\frac{(\bar{w}-c) y_{i}\left(k_{i}^{*}\right)}{\gamma_{i}\left(\partial^{2} \Pi / \partial k_{i}^{2}\right)} .
$$

Using the second-order condition, it follows that $\partial k_{i}^{*} / \partial \alpha<0$ when $\bar{w}>$ c.

The more bargaining power unions possess, the higher are wages and thus in-house production costs. Nevertheless, more powerful unions reduce the incentives for outsourcing. In other words, higher in-house production costs make outsourcing less profitable. This apparently counterintuitive result can be explained along the same lines as Proposition 2. When $\bar{w}>c$, outsourcing increases total rents and yields higher operating profits. However, a more powerful union is able to capture a larger share of this rent increase by enforcing higher wages for the remaining in-house production, thereby making outsourcing less profitable. A process of deunionization, with a subsequent reduction of union bargaining strength, will consequently increase the degree of international outsourcing in equilibrium.

It should be noted that there are also alternative ways to interpret deunionization. One obvious interpretation - which is perhaps more 
consistent with the empirical use of union coverage as a measure of the degree of unionization - is that some firms become non-unionized while others continue to be unionized with equally strong unions. ${ }^{20}$ However, this changes only the interpretation, and not the substantive content, of our results. In this case, equilibrium outsourcing intensity will increase in firms that become non-unionized (due to the monotone relationship between $\alpha$ and $k^{*}$ ), and remain constant in other firms. Consequently, the overall level of outsourcing increases.

\section{Technology}

How are outsourcing incentives and the impact of deunionization affected by productive efficiency? From (16) we can derive

$$
\frac{\partial k_{i}^{*}}{\partial \gamma_{i}}=-\frac{(1+\alpha \mu)^{-1}(\bar{w}-c) y_{i}\left(k_{i}^{*}\right)}{\mu \gamma_{i}^{2}\left(\partial^{2} \Pi_{i} / \partial k_{i}^{2}\right)}>0,
$$

implying that more efficient firms have stronger incentives for outsourcing. The reason is simply that firms with better technology have a larger share of the market, which, in turn, implies that total variable cost savings from cutting marginal production costs are larger. Thus, incentives for international outsourcing - which is precisely a way to reduce marginal production costs - are stronger for the more efficient firms.

For the same reason, increased outsourcing incentives due to deunionization are more pronounced in firms with superior technology. ${ }^{21} \mathrm{In}$ other words, the main bulk of the increased outsourcing due to deunionization is undertaken by the technologically stronger firms. Since outsourcing incentives are stronger for the more efficient firms to begin with, this means that, for a given technological distribution, deunionization increases the differences in outsourcing intensities between efficient and inefficient firms. ${ }^{22}$

\footnotetext{
${ }^{20}$ Machin (2000) underlines that union decline in Britain typically has taken the form that union membership falls because new firms in 'new' industries are not unionized, while many existing firms in traditional industries keep their level of unionization. Checci and Visser (2005) broadly confirm this view for Western Europe, but also point at other factors that have driven deunionization.

${ }^{21}$ It is easily shown that the absolute value of $\partial k_{i}^{*} / \partial \alpha$ increases in $\gamma_{i}$.

${ }^{22}$ Technological differences may also apply to in-house production of inputs. With this interpretation, the relationship between productive efficiency and outsourcing
} 


\section{$5 \quad$ Globalization and outsourcing}

Having established the main results of the paper, the purpose of this Section is to discuss how our model can be used to say something about the relationship between globalization and outsourcing. Of course, international outsourcing can in itself be considered as a characteristic of the broad term 'globalization'. Our aim, though, is to see whether we can identify increased outsourcing as a causal consequence of some typically identified product market characteristics of globalization.

Globalization may of course reduce the direct costs of international outsourcing, by reducing both the variable cost $c$ (e.g., through reduced transportation costs) and the fixed costs $g(j)$. It is straightforward to show that both types of cost reductions will lead to increased outsourcing. We will, however, focus on two commonly observed, and partly related, features of globalization with respect to the final goods market, namely market integration and increased competition.

\section{Market integration}

The effects of market integration have been extensively studied in the literature on international trade, ${ }^{23}$ where the focus is typically on how market expansion affects product variety through entry of new firms. But how does an increase in the size of the market affect incentives for international outsourcing? The obvious strategy in the context of the present model is to interpret market integration as an increase in the demand parameter $\Gamma$. From the first-order condition for firm $i$ 's optimal outsourcing decision, we can easily derive

$$
\frac{\partial k_{i}^{*}}{\partial \Gamma}=-\frac{(1+\alpha \mu)(\bar{w}-c) y_{i}\left(k_{i}^{*}\right)}{\left(\partial^{2} \Pi_{i} / \partial k_{i}^{2}\right) \gamma_{i} \Gamma}>0,
$$

which implies that market integration increases the optimal degree of outsourcing. The intuition follows the above discussion of productive

incentives is generally ambiguous. In addition to the indirect effect through total output, better technology also directly implies that the firm is more efficient relative to foreign sub-contractors, which - all else equal - reduces outsourcing incentives.

${ }^{23}$ For some early studies, see Krugman $(1979,1980)$ and Helpman (1981). 
efficiency and outsourcing incentives. A larger market increases demand and thus output for each firm, which increases incentives for cutting marginal production costs. This result is also closely related to the literature on process innovation, where firms undertake R\&D investments in order to reduce marginal production costs. A standard result from this literature is that $R \& D$ expenditures per firm increase with the size of the market (see, e.g., Dasgupta and Stiglitz, 1980). In our model, international outsourcing resembles process innovation in that it requires a costly investment to reduce marginal production costs.

\section{Increased competition}

Within the context of product market competition, globalization does not only imply that markets expand, but also that firms face fiercer competition in their respective markets. So how does increased competition affect incentives for outsourcing? We can use the parameter $\sigma$ (the price elasticity of demand) as a direct measure of the degree of competition between firms. In a similar type of model, Blanchard and Giavazzi (2003) argue that economic integration is likely to increase $\sigma$ as a result of the elimination of tariff barriers, or standardization measures that increase the substitutability among products. ${ }^{24}$

If we consider the demand function (3), an increase in $\sigma$ has two different effects. In addition to an increase in demand elasticity, it also generally increases or reduces demand - for given prices - depending on whether $p_{i}$ is below or above unity. We are only interested in the former effect, though, since the demand effect on outsourcing incentives has been captured by the above discussion of market size. We can isolate the elasticity effect by evaluating the effect of a marginal change in $\sigma$ at $p_{i}\left(k_{i}^{*}\right)=1$. By total differentiation of (16), and after some manipulation, the effect of increased competition on outsourcing incentives can

\footnotetext{
${ }^{24}$ Blanchard and Giavazzi also make the assumption that the elasticity of substitution between products is an increasing function of the number of firms/products in the market. It is important to note, though, as Blanchard and Giavazzi also stress, that by interpreting an increase in $\sigma$ as a result of globalization or economic integration, one should think of $\sigma$ not as a taste parameter in a utility function, but rather interpret the underlying CES function as a reduced form reflecting the substitutability among products.
} 
be expressed as

$$
\left.\frac{\partial k^{*}}{\partial \sigma}\right|_{p_{i}\left(k_{i}^{*}\right)=1}=-\frac{\mu[1+\alpha(1+\mu)](\bar{w}-c) y_{i}\left(k_{i}^{*}\right)}{\gamma_{i}\left(\partial^{2} \Pi_{i} / \partial k_{i}^{2}\right)}>0 .
$$

Thus, increased competition between firms will also increase incentives for international outsourcing. Two different mechanisms contribute to this result. First, fiercer competition forces the firms to lower their prices and expand output, which, similar to the case of market expansion, increases the gain of reducing marginal production costs. In addition, increased competition increases labor demand elasticity. This reduces the wage response to outsourcing, as can be seen from (8), making outsourcing more profitable for firms.

\section{Extensions}

So far we have conducted our analysis under the assumptions that trade unions seek to maximize the sum of rents accruing to unionized workers, and that the firms have full discretionary power over employment decisions. In this Section we will investigate to what extent our results are robust to changes in each of these assumptions, by separately considering the alternative assumptions of efficient bargaining and union preferences that differs from rent-maximization.

\subsection{Efficient bargaining}

The 'right-to-manage' model of wage bargaining (henceforth RTM) is widely used in trade union models, for fairly convincing reasons. Not only does it correspond to the real-world observation that firms usually set employment unilaterally; it also ensures incentive compatibility by producing wage-employment outcomes on the labour demand schedule. However, the RTM model is sometimes criticized on the grounds that it does not yield Pareto-efficient outcomes for the bargaining parties. Let us therefore consider the alternative assumption of efficient bargaining (henceforth EB), where each firm-union pair bargain over both wages and employment.

In our model, bargaining over employment is equivalent to bargaining 
over price levels, so the bargaining game under EB is characterized by

$$
\max _{w_{i}, p_{i}} \Omega_{i}=\alpha \ln U_{i}+(1-\alpha) \ln \pi_{i}
$$

where $U_{i}$ and $\pi_{i}$ are given by (2) and (4), respectively. The solution to this maximization problem yields the following equilibrium wage and price levels:

$$
\begin{gathered}
w_{i}\left(k_{i}\right)=(1+\alpha \mu) \bar{w}+\left(\frac{k_{i}}{\phi-k_{i}}\right) \alpha \mu c, \\
p_{i}\left(k_{i}\right)=\gamma_{i}^{-1}(1+\mu) \bar{\omega}_{i} .
\end{gathered}
$$

Comparing with the RTM model, we see that the wage level is the same under EB, but the price is lower, since the double marginalization effect of RTM bargaining is eliminated under EB. For a given level of outsourcing, the operating profit of firm $i$ is found by inserting (19) and (20) into (3) and (4), yielding

$$
\pi_{i}\left(k_{i}\right)=(1-\alpha) \mu(1+\mu)^{-\sigma} \gamma_{i}^{\sigma-1} \Gamma \bar{\omega}_{i}^{1-\sigma} .
$$

The first-order condition for the optimal degree of outsourcing by firm $i$ is then given by

$$
\frac{\partial \Pi_{i}}{\partial k_{i}}=(1-\alpha)(\bar{w}-c) \gamma_{i}^{-1} y_{i}\left(k_{i}^{*}\right)-G^{\prime}\left(k_{i}^{*}\right)=0 .
$$

We immediately see that $\bar{w}>c$ is a necessary condition for $k_{i}^{*}>0$. Furthermore, since the output price (and thus output) does not depend on $\alpha$, it follows directly from (21) that a weaker trade union will increase incentives for outsourcing. Thus, all our main results (Propositions 1-3) hold also under the assumption of EB. Given the workings of the model, this should come as no surprise. Perhaps more interesting, though, is a direct comparison between RTM and EB with respect to outsourcing incentives.

Proposition 4 If $\alpha>0$, the optimal degree of outsourcing is lower under EB, compared with RTM.

Proof. $\left.k^{*}\right|_{E B}<\left.k^{*}\right|_{R T M}$ if $\left.\frac{\partial \Pi_{i}}{\partial k_{i}}\right|_{R T M}>\left.\frac{\partial \Pi_{i}}{\partial k_{i}}\right|_{E B}$ for all $k \in[0, \phi]$. From 
(16) and (21), it is easily shown that this condition is satisfied if $D(\alpha):=$ $(1+\alpha \mu)^{1-\sigma}-(1-\alpha)>0$. This holds for all $\alpha>0$, since $D(0)=0$ and $\frac{\partial D}{\partial \alpha}=-(1+\alpha \mu)^{-\sigma}+1>0$.

Stronger outsourcing incentives under RTM bargaining are explained by the fact that RTM bargaining provides the firms with an extra rentextracting instrument, namely the possibility to freely adjust employment in response to a wage change. We know that outsourcing leads to increased wages for the remaining in-house production, because the trade unions will capture parts of the rent increase by enforcing higher wages. Under RTM, the firms can partly offset this effect by reducing output (increase prices). Under EB, though, this is no longer possible, implying that outsourcing incentives are reduced. Furthermore, the difference between outsourcing incentives under RTM and EB increases with the relative bargaining strength of unions. This is most clearly seen for the limit case of $\alpha=1$, where the unions capture all monopoly rents under EB.

\subsection{Employment-oriented unions}

We have seen that a rent-maximizing trade union will always benefit from outsourcing, since a loss of employment can be more than compensated for by an increase in wages. However, this appears to run contrary to the observation that trade unions often oppose outsourcing. Thus, it may be that many unions place a larger emphasis on employment, relative to wages. We can incorporate this possibility by considering the following union utility function:

$$
U_{i}=\left(w_{i}-\bar{w}\right)^{\theta} n_{i}, \quad \theta>0 .
$$

An employment oriented union would now be characterized by $\theta<1$.

Retreating now to the basic model of RTM bargaining, and using the modified utility function (22) in the Nash maximand (7), the bargained 
wage is given by ${ }^{25}$

$$
w_{i}\left(k_{i}\right)=\Psi\left[\bar{w}+\left(\frac{k_{i}}{\phi-k_{i}}\right)\left(\frac{\theta \alpha c}{\mu^{-1}+\alpha}\right)\right]
$$

where

$$
\Psi:=\frac{\mu^{-1}+\alpha}{\mu^{-1}+\alpha(1-\theta)} .
$$

We see that the bargained wage is still an increasing function of the degree of outsourcing, but the strength of the wage response to outsourcing is lower the more employment oriented the union is. Using (23), it can also be shown that the union will oppose outsourcing, i.e., $\frac{\partial U_{i}}{\partial k_{i}}<0$, if $\theta<\theta^{*}:=\sigma-(\sigma-1) \frac{\bar{\omega}_{i}}{c \phi}$. If the union is sufficiently concerned about employment, relative to wages, an employment loss due to outsourcing cannot be fully compensated for by the subsequent wage increase for the remaining union workers. ${ }^{26}$

From (23) we can derive the equilibrium values of prices and profits:

$$
\begin{gathered}
p_{i}\left(k_{i}\right)=\Psi \gamma_{i}^{-1}(1+\mu) \bar{\omega}_{i}, \\
\pi_{i}\left(k_{i}\right)=\mu \Gamma \gamma_{i}^{\sigma-1} \Psi^{1-\sigma} \bar{\omega}_{i}^{1-\sigma}(1+\mu)^{-\sigma} .
\end{gathered}
$$

The first-order condition for the optimal level of outsourcing for firm $i$ is then given by

$$
\frac{\partial \Pi_{i}}{\partial k_{i}}=\Psi^{1-\sigma}(\bar{w}-c) \gamma_{i}^{\sigma-1} \Gamma \bar{\omega}_{i}^{-\sigma}(1+\mu)^{-\sigma}-G^{\prime}\left(k_{i}^{*}\right)=0 .
$$

Once more, $\bar{w}>c$ is a necessary condition for $k_{i}^{*}>0$. Furthermore, it is easily shown that $\partial \Pi_{i}^{2} / \partial k_{i} \partial \alpha<0$, which confirms the robustness of Proposition 3: weaker unions lead to stronger outsourcing incentives. A related result is the following:

Proposition 5 More employment oriented unions lead to increased international outsourcing.

\footnotetext{
${ }^{25}$ Fulfilment of the second-order condition requires that $\mu^{-1}>-\alpha(1-\theta)$. This is always true if $\theta \leq 1$.

${ }^{26}$ Since $c \phi<\bar{\omega}_{i}$, we see that $\theta^{*}<1$.
} 
Proof. By total differentiation of (26) we derive

$$
\frac{\partial k^{*}}{\partial \theta}=\frac{\Psi^{2} \alpha \mu^{-1}(\bar{w}-c) y_{i}\left(k_{i}^{*}\right)}{\left(\partial^{2} \Pi / \partial k_{i}^{2}\right) \gamma_{i}\left(\mu^{-1}+\alpha\right)}<0 .
$$

The intuition behind this result lies in the union's wage response to outsourcing. As (23) clearly shows, the more concerned a union is about employment (i.e., the lower $\theta$ is), the smaller is the wage increase triggered by outsourcing. Obviously, the firms' outsourcing incentives will be correspondingly stronger. This result also implies that the potential for a conflict of interest between the firm and its unionized workers is larger when the union is employment oriented, not only because outsourcing is then more likely to reduce union utility, but also because more employment oriented unions increase the firms' outsourcing incentives.

\section{Concluding remarks}

By way of conclusion, we would like to discuss some of the assumptions underlying our results. A main result was that deunionization can trigger international outsourcing. In its literal version, this result builds on the assumption that it is not economically possible to outsource the last task performed by unionized workers. So whenever a task is outsourced, there are always some workers that remain and experience that the demand for their labor becomes less elastic, which makes them push their wages up.

What if this was not the case? The organizational structure decision of the firm would then be a two-tier one in the following sense: First, the firm would have to decide how many tasks that should be outsourced and how many should remain at home, given that the firm should keep some domestic presence. Then it would have to decide whether to go for this solution of partial outsourcing - or choose to offshore the firm in its entirety to a foreign location. Weaker unions would then presumably imply that given that the firm retains its domestic presence, the level of outsourcing goes up - but the likelihood that the whole firm is offshored 
goes down.

More complex issues arise if one should introduce heterogenous workers in the model. For example, would there be a systematic tendency that tasks that are easy to outsource also are the ones that are least intensive in skills? Moreover, would it be natural to retain the oneunion-per-firm assumption? Perhaps some workers with a very high skill level can bargain successfully on the individual level? Modelling options are many. What could threaten the main logic behind the present results would be if workers were sorted in different unions - and that there was a systematic tendency that the more tasks that were outsourced, the weaker is the bargaining strength of the remaining workers. However, that would not nullify the mechanisms we have highlighted here, but would introduce an effect that run counter to the effects we have studied. ${ }^{27}$

Finally, let us briefly make some comments about the efficiency properties of the model. A central result in our analysis is is that strong unions can protect an economy from outsourcing of jobs, and even more so in high-tech industries. This is seemingly at odds with the idea that trade unions constitute a departure from free market competition, but only seemingly so. Grout (1984) and Manning (1987) pointed out that strong unions could deter investments prior to a unionized wageemployment settlement. The same type of inefficiency is present here. The firms invest in setting up import channels for inputs, but if unions are too strong, the firm owners capture too little of the total gains from this investment. In consequence, domestic employment is inefficiently high. Of course, one could speculate that there are positive exernalities from the saved jobs, which would overturn the inefficiency result, but this discussion is outside the scope of this paper.

\footnotetext{
${ }^{27}$ A recent paper by Antràs, Garicano and Rossi-Hansberg (2006) studies offshoring in a knowledge economy. We think it would be interesting to study the interplay between outsourcing and offshoring decisions in such an economy, where workers to a varying degree have bargaining power, but this is left for further research.
} 


\section{References}

[1] Antràs, P., Garicano, L. and E. Rossi-Hansberg, 2006. Offshoring in a knowledge economy. Quarterly Journal of Economics, 121, 31-77.

[2] Antràs, P. and E. Helpman, 2004. Global sourcing. Journal of Politcal Economy, 112, 552-580.

[3] Blanchard, O.J. and F. Giavazzi, 2003. Macroeconomic effects of regulation and deregulation in goods and labor markets. Quarterly Journal of Economics, 118, 879-907.

[4] Checci, D. and J. Visser, 2005. Pattern persistence in European trade union density - A longitudinal analysis 1950-1996. European Sociological Review, 21, 1-21.

[5] Chen, Y., Ishikawa, J. and Z. Yu, 2004. Trade liberalization and strategic outsourcing. Journal of International Economics, 63, 419436.

[6] Choi, J.P. and C. Davidson, 2004. Strategic second sourcing by multinationals. International Economic Review, 45, 579-600.

[7] Dasgupta, P. and J.E. Stiglitz, 1980. Industrial structure and the nature of innovative activity. Economic Journal, 90, 266-293.

[8] Dell'Aringa, C., Lucifora, C., Orlando, N. and E. Cottini, 2004. Bargaining structure and intra-establishement pay inequality in four European countries: Evidence from matched employer-employee data. Downloadable from http://cep.lse.ac.uk/piep/papers/Bargaining_structure _and_intraestablishment_pay_inequality.pdf

[9] Dixit, A. and V. Norman, 1980. The theory of international trade. Cambridge University Press.

[10] Dowrick, S. and B. Spencer, 1994. Union attitudes to labour-saving innovation: when are unions Luddites. Journal of Labor Economics, $12,316-344$.

[11] EEAG (European Economic Advisory Group), 2004. Report on the European economy 2004. Munich: CESifo.

[12] Feenstra, R. and G. Hanson, 1999. The impact of outsourcing and high-technology capital on wages: estimates for the United States 1979-1990. Quarterly Journal of Economics, 114, 907-940. 
[13] Geishecker, I. and H. Görg, 2004. International outsourcing and wages: winners and losers. Manuscript, DIW Berlin.

[14] Glass, A.J. and K. Saggi, 2001. Innovation and wage effects of international outsourcing. European Economic Review 45, 67-86.

[15] Grossman, G.M. and E. Helpman, 2002. Integration versus outsourcing in industry equilibrium. Quarterly Journal of Economics, $117,85-120$.

[16] Grossman, G.M. and E. Helpman, 2003. Outsourcing versus FDI in industry equilibrium. Journal of the European Economic Association, 1, 317-327.

[17] Grossman, G.M. and E. Helpman, 2005. Outsourcing in a global economy. Review of Economic Studies, 72, 135-159.

[18] Grout, P.A., 1984. Investment and wages in the absence of binding contracts - a Nash bargaining approach. Econometrica, 52, 449-460.

[19] Görg, H., Hijzen, A. and R. Hine, 2005. International outsourcing and the skill structure of labour demand in the United kingdom. Economic Journal, 115, 860-878.

[20] Helpman, E., 1981. International trade in the presence of product differentiation, economies of scale, and monopolistic competition: a Chamberlin-Heckscher-Ohlin approach. Journal of International Economics, 11, 305-340.

[21] Horn, H. and A. Wolinsky, 1988. Worker subsitutability and patterns of unionisation. Economic Journal, 98, 484-497.

[22] Kohler, W., 2004. International outsourcing and factor prices with multistage production. Economic Journal, 114, C166-C185.

[23] Krugman, P.R., 1979. Increasing returns, monopolistic competition, and international trade. Journal of International Economics, 9, 469480

[24] Krugman, P.R., 1980. Scale economics, product differentiation, and the pattern of trade. American Economic Review, 70, 950-959.

[25] Lommerud, K.E., Meland, F. and L. Sørgard, 2003. Unionised oligopoly, trade liberalisation and location choice. Economic Journal, 113, 782-800.

[26] Lommerud, K.E., Meland, F. and O.R. Straume, 2006. Globalisa- 
tion and union attitudes towards technological change. Journal of International Economics, 68, 1-23.

[27] Lommerud, K.E., Straume, O.R. and L. Sørgard, 2006. National versus international mergers in unionised oligopoly. RAND Journal of Economics, forthcoming.

[28] Lyons, B.R. and K. Sekkat, 1991. Strategic bargaining and vertical separation. Journal of Industrial Economics, 39, 577-593.

[29] Machin, S., 2000. Union decline in Britain. British Journal of Industrial Relations, 38, 631-645.

[30] Manning, A., 1987. An integration of trade-union models in a sequential bargaining framework. Economic Journal, 97, 121-139.

[31] Markusen, J., 1995. The boundaries of multinational enterprises and the theory of international trade. Journal of Economic Perspectives, 9, 169-189.

[32] Naylor, R., 1998. International trade and economic integration when labour markets are generally unionised. European Economic Review, 42, 1252-1267.

[33] Naylor, R., 1999. Union wage strategies and international trade. Economic Journal, 109, 102-125.

[34] OECD, 1997. Economic performance and the structure of collective bargaining. In OECD Employment Outlook. Paris: OECD

[35] Shy, O. and R. Stenbacka, 2003. Strategic outsourcing. Journal of Economic Behavior \& Organization, 50, 203-224.

[36] Skaksen, M.Y. and J.R. Sørensen, 2001. Should trade unions appreciate foreign direct investment. Journal of International Economics, 55, 379-390.

[37] Staiger, R., 1988. Organized labor and the scope of international specialization. Journal of Political Economy, 96, 1022-1047.

[38] Thesmar, D. and M. Thoenig, 2002. From flexibility to insecurity: the way outsourcing amplifies uncertainty. CEPR Discussion Paper No. 3629.

[39] Yeats, A. J., 2001. Just how big is global production sharing? In Arndt, S.W. and H. Kierzkowski, Fragmentation: New production patterns in the world economy, Oxford University Press. 
[40] Zhao, L., 2001. Unionization, vertical markets, and the outsourcing of multinationals. Journal of International Economics, 55, 187-202. 